\title{
Welcome to the 19th volume of Pharmacogenomics
}

\author{
Sarah Jones ${ }^{*}, 1$ \\ ${ }^{1}$ Future Science Group, Unitec House, 2 Albert Place, London N31QB, UK \\ * Author for correspondence: s.jones@futuremedicine.com
}
' In 2018 Phamacogenomics will be renewing our commitment to publish the latest cutting edge research as well as insightful and topical reviews and perspective papers."

First draft submitted: 6 December 2017; Accepted for publication: 12 December 2017; Published online: 14 December 2017

Keywords: CYP2D6 • high-impact research • pharmacogenomics • topical reviews

I would like to wish all our readers a happy new year and to introduce you to the 19th volume of Pharmacogenomics. In this Foreword I would like to present some selected highlights of 2017 and also look forward to the year ahead.

\section{Looking back: 2017}

2017 has seen Pharmacogenomics publish novel, high-impact research over a wide range of topics. The most read research article of 2017 was a pilot study of the effect of CYP2D6 genotype on amitriptyline efficacy for the treatment of diabetic peripheral neuropathy by Chaudhry et al. Amitriptyline is used to treat painful diabetic neuropathy and this preliminary study aimed to examine the role of the CYP2D6 gene in side effects associated with treatment. CYP2D6 genotype was found to contribute to treatment outcome and as a consequence could be useful for guiding amitriptyline treatment [1].

The second most read article was a genome-wide association study of genetic variants associated with angiotensinconverting enzyme inhibitor-induced cough. The study found a putative association between genes independent of the bradykinin pathway and angiotensin-converting enzyme inhibitor-induced cough [2].

In line with the developing relationship between pharmacogenomics and other omic disciplines, we published a Special Focus issue on pharmacoepigenomics in September. Highlights of this issue include an epigenome-wide association study of inflammatory response to fenofibrate which is the first methylome profile of the lipid-lowering efficacy of a PPAR- $\alpha$ inhibitor [3].

\section{Looking forward: 2018}

In 2018 Phamacogenomics will be renewing our commitment to publish the latest cutting edge research as well as insightful and topical reviews and perspective papers.

During the course of the year, we'll be making high-impact research articles free to access for a limited period. The most recent articles chosen to be free to access by our Editor in Chief Professor David Gurwitz and are below:

- Yusuf $\mathrm{N}$ et al. An epigenome-wide association study of inflammatory response to fenofibrate in the Genetics of Lipid Lowering Drugs and Diet Network [4];

- Borse MS et al. CYP2C19-guided antiplatelet therapy: a cost-effectiveness analysis of 30 day and 1 year outcomes following percutaneous coronary intervention [5];

- Liu et al. Influence of common and rare genetic variation on warfarin dose among African-Americans and European-Americans using the exome array [6];

- Daud ANA et al. Prenatal exposure to serotonin reuptake inhibitors and congenital heart anomalies: an exploratory pharmacogenetics study [7].

As routine pharmacogenetic testing moves closer to the clinic, we hope to provide a key resource for researchers within this continually developing field. 


\section{Conclusion}

We appreciate all feedback from the pharmacogenomics community regarding the direction of our content, especially suggestions of any priority topics in the field that you feel the journal should cover. We welcome unsolicited research, review and opinion article proposals, amongst others, and would be delighted to hear from you if you are interested in submitting to the journal.

I would also like to take this opportunity to thank our readers, contributing authors, valued Editorial Board members and peer reviewers for their continued support and collaboration as we continue to publish the latest cutting-edge research. We very much look forward to working with you all over the next year.

\section{Financial \& competing interests disclosure}

$S$ Jones is an employee of Future Science Ltd, publisher of Pharmacogenomics. The author has no other relevant affiliations or financial involvement with any organization or entity with a financial interest in or financial conflict with the subject matter or materials discussed in the manuscript apart from those disclosed.

No writing assistance was utilized in the production of this manuscript.

\section{References}

Papers of special note have been highlighted as: $\bullet$ of interest; $\bullet \bullet$ of considerable interest

1 Chaudhry M, Alessandrini M, Rademan J et al. Impact of CYP2D6 genotype on amitriptyline efficacy for the treatment of diabetic peripheral neuropathy: a pilot study. Pharmacogenomics 8(5), 433-443 (2017).

2 Hallberg P, Persson M, Axelsson T et al. Genetic variants associated with angiotensin-converting enzyme inhibitor-induced cough: a genome-wide association study in a Swedish population. Pharmacogenomics 8(3), 201-213 (2017).

3 Yusuf N, Hidalgo B, Irvin MR et al. An epigenome-wide association study of inflammatory response to fenofibrate in the Genetics of Lipid Lowering Drugs and Diet Network. Pharmacogenomics 18(14), 1333-1341 (2017).

4 Borse MS, Dong OM, Polasek MJ, Farley JF, Stouffer GA, Lee CR. CYP2C19-guided antiplatelet therapy: a cost-effectiveness analysis of 30 day and 1 year outcomes following percutaneous coronary intervention. Pharmacogenomics 18(12), 1155-1166 (2017).

5 Liu N, Irvin MR, Zhi D et al. Influence of common and rare genetic variation on warfarin dose among African-Americans and European-Americans using the exome array. Pharmacogenomics 18(11), 1059-1073 (2017).

6 Daud ANA, Bergman JEH, Kerstjens-Frederikse WS et al. Prenatal exposure to serotonin reuptake inhibitors and congenital heart anomalies: an exploratory pharmacogenetics study. Pharmacogenomics 18(10), 987-1001 (2017). 